\title{
ANGIOGENESIS INHIBITORS GENERATED BY TUMORS
}

\author{
Judah Folkman, M.D. \\ Children's Hospital and Harvard Medical School, Boston, \\ Massachusetts, U.S.A.
}

Growth regulation in the vascular system appears to be a deceptively simple process. In large vessels, endothelial cells can migrate and proliferate to maintain a monolayer facing the blood; smooth muscle cells can migrate and proliferate to form multiple layers in the vessel wall. In microvessels, similar migratory and proliferative capacities of endothelial cells and pericytes generate capillary tubes which can grow, remain quiescent, or involute. However, the cellular and molecular mechanisms which govern these events are very complex. Thus, while several growth factors which operate in the vascular system have been isolated and purified during the past two decades, we have only a limited understanding of how these proteins are regulated.

\section{STIMULATORS AND INHIBITORS OF ANGIOGENESIS}

Much of our current knowledge about growth control of microvessels has come from the study of tumor angiogenesis, a research effort driven by the hypothesis that tumor growth is angiogenesis dependent (1-3). The implication of this hypothesis is that if the regulation of angiogenesis could be understood well enough that tumor angiogenesis could be controlled, this would lead to an additional therapeutic approach to cancer. This idea was the basis for studies of the in vitro culture of capillary endothelial cells, the development of bioassays for angiogenesis (for review see Ref. 4), the identification and sequencing of at least 8 angiogenic proteins (5), and the discovery of angiogenesis inhibitors (6).

The majority of the angiogenic proteins were originally isolated from tumor cells and subsequently found to be present in many normal tissues. In contrast, there was no rational method of discovering angiogenesis inhibitors except to analyze avascular tissues such as cartilage $(7,8)$. Most of the currently known angiogenesis inhibitors were discovered accidentally (e.g., protamine, platelet factor 4, angiostatic steroids, and several derivatives of fungi and bacteria) $(9,10)$. Subsequently, small molecular weight inhibitors of signal transduction (11) or of metalloproteinases (12) were also found to inhibit angiogenesis.

\section{DISCOVERY OF ANGIOGENESIS INHIBITORS GENERATED BY TUMORS: THROMBOSPONDIN AND ANGIOSTATIN}

Since the early days of angiogenesis research (1970s), it has seemed that the least likely place to look for novel angiogenesis inhibitors would be in a tumor. Even after a study of tumors arising spontaneously in transgenic mice (13) revealed a rather sudden "switch" to the angiogenic phenotype during tumorigenesis, this was explained mainly on the basis of up-regulation of angiogenic factors. It was demonstrated that these positive regulators of angiogenesis could be exported from tumor cells (14), or mobilized from extracellular matrix (15), or released from host cells (e.g., macrophages) recruited to the tumor (16).

There were, however, a few clues to suggest that positive regulators of angiogenesis were necessary but not sufficient for the angiogenic phenotype. Rat chondrosarcomas were found to produce high levels of bFGF before and after they became angiogenic (17). Tumors arising from $\beta$ cells in the islets of transgenic mice (13) expressed equivalently high levels of acidic fibroblast growth factor (aFGF) and vascular endothe- 
lial growth factor (VPF/VEGF) before and after they became angiogenic (Y. Shing, unpublished data). Furthermore, inhibitors of endothelial growth (TGF- $\beta$, TIMPs, and an unidentified endothelial inhibitor) were purified from the conditioned medium of vascularized tumors (Y. Shing, unpublished data).

However, the realization that the angiogenic phenotype may be a net balance between positive and negative regulators of capillary blood vessel growth did not emerge until Bouck and her colleagues first demonstrated that a natural inhibitor of angiogenesis was down-regulated during the switch to the angiogenic phenotype (18). It was found that normal hamster cells express high levels of thrombospondin, an inhibitor of endothelial proliferation and of angiogenesis (19). Upon undergoing malignant transformation, the hamster cells switched to the angiogenic phenotype and down-regulated thrombospondin expression to $4-6 \%$ of the preangiogenic parent cell. It was later shown that in normal human fibroblasts, thrombospondin is under the control of the p53 tumor suppressor gene (20).

Taken together, these results led us to hypothesize that perhaps a primary tumor could release into the circulation residual negative regulators of angiogenesis which would inhibit neovascularization in a remote metastasis (21). This model could possibly help to explain a long unsolved problem of how tumor mass can suppress tumor growth (22).

The rationale for this hypothesis was that while individual tumor cells may produce only $4-6 \%$ of the thrombospondin produced by their normal precursor cells, a tumor mass containing a billion cells could generate significant quantities of such an inhibitor. If this putative inhibitor diffused into the circulation and was cleared less rapidly than angiogenic stimulators (e.g., approximately $3 \mathrm{~min}$ for VEGF and $30 \mathrm{~min}$ for bFGF), then the inhibitor could suppress angiogenesis in remote metastases. This idea led to the discovery of a novel angiogenesis inhibitor, 'angiostatin,' that accumulates in the circulation in the presence of a growing primary tumor and disappears when the tumor is removed (21). Angiostatin is a $38-\mathrm{kD}$ protein with $>98 \%$ homology to an internal fragment of plasminogen; having an $\mathrm{N}$ terminus at amino acid 98 and an approximate $C$ terminus at amino acid 440 . It is a specific inhibitor of endothelial cell proliferation detectable in the serum in the presence of the primary tumor. Angiostatin disappears from the circulation by 5 days after removal of the primary tumor. Metastases, which were unable to induce angiogenesis and remained dormant in the presence of the primary tumor, were suddenly neovascularized and grew rapidly after removal of the primary tumor.

While it is not clear at this writing whether angiostatin is produced directly or indirectly by the primary tumor, the inhibitor profoundly suppresses angiogenesis in remote metastases. In the resulting dormant metastases, tumor cells have a high replication rate, balanced by a high rate of apoptosis (J. Folkman, unpublished data). The metastases themselves do not expand beyond a diameter of approximately $250 \mu \mathrm{m}$. In the neovascularized metastases, there is little or no change in the high replication rate, but the apoptotic rate is significantly decreased and the metastases may enlarge to $>500$ times their dormant size. The therapeutic administration of angiostatin is inhibitory to a primary tumor (T/C 0.2 to 0.3 ) as well as to its metastases.

A third tumor-derived angiogenesis inhibitor was recently identified in a human brain tumor (23). In this experiment, Cavenee and his associates transfected the wild-type p53 tumor suppressor gene into highly angiogenic human glioblastoma cells, thus rendering them nonangiogenic. An angiogenesis inhibitor was isolated from the conditioned medium of these cells but has not yet been completely characterized.

\section{RESEARCH AND CLINICAL IMPLICATIONS}

Three novel strategies for discovering endogenous angiogenesis inhibitor molecules now exist: (i) the down-regulation of angiogenesis inhibitor activity can be analyzed at the switch to the angiogenic phenotype during tumorigenesis (18); (ii) antiangiogenic activity can be revealed by transfection of an angiogenic tumor with a tumor suppressor gene (23); and (iii) circulating angiogenesis inhibitor activity can be purified from serum or urine of mice bearing a tumor which suppresses its metastases (21).

One can speculate on the potential clinical implications of this new knowledge. It may eventually be possible to determine if a cancer patient has circulating endothelial inhibitor activity and whether or not this protects against recurrent metastasis. Therapeutic replacement of antiangiogenic activity may be considered after 
surgical removal of a tumor. We have demonstrated the ability of angiostatin therapy in mice to suppress metastatic growth after removal of the primary tumor (21). Maintenance of dormant metastases in mice by angiostatin suggests a model in which angiogenic control of metastatic growth is a general mechanism of dormancy in human cancer (J. Folkman, unpublished data and 23).

Finally, the discovery of traces of angiogenesis inhibitors which are generated by vascularized tumors suggests that these proteins may have a physiological role which remains to be elucidated.

\section{REFERENCES}

1. Folkman J. (1971) N. Engl. J. Med. 285: 1182-1186.

2. Folkman J. (1990) J. Natl. Cancer Inst. 82: 4-6.

3. Folkman J. (in press) In: Mendelsohn J, Howley P, Llotta L, Israel M (eds). The Molecular Basis of Cancer. W. B. Saunders, Philadelphia.

4. Folkman J. (1985) In: Important Advances in Oncology 1985. DeVita VT, Hellman S, Rosenberg SA (eds). J. B. Lippincott, Philadelphia, pp. 42-62.

5. Folkman J, Shing Y. (1992) J. Biol. Chem. 267: 10931-10934.

6. Folkman J. (1991) In: Biologic Therapy of Cancer. DeVita VT, Hellman S, Rosenberg SA (eds). J. B. Lippincott, Philadelphia, pp. 743753.

7. Eisenstein R, Sorgente N, Soble L, Miller A, Kuettner K. (1973) Am. J. Pathol. 73: 785774.

8. Moses MA, Sudhalter J, Langer R. (1990) Science 248: 1408-1410.
9. Ingber D, Fujita $T$, Kishimoto $S$, Sudo K, Brem H, Folkman J. (1990) Nature 348: 555557.

10. Oikawa $T$, Hasegawa $M$, Shimamura $M$, Ashino H, Muroto S, Morita I. (1991) Biochem. Biophys. Res. Commun. 181: 1070-1076.

11. Alesendro R, Spoonster J, Liotta LA, Kohn E. (1994) Proc. Am. Assoc. Cancer Res. 35: (Abstract 1102):184.

12. Beattle GJ, Young HA, Smyth JF. (1994) Ann. Oncol. 5: (Abstract 015):72.

13. Folkman J, Watson K, Ingber D, Hanahan D. (1989) Nature 339: 58-61.

14. Kandel J, Bossy-Wetzel E, Radvanyl F, Klagsbrun M, Folkman J, Hanahan D. (1991) Cell 66: 1095-1 104.

15. Vlodavsky I, Korner G, Ishai-Michaeli R, Baskin P, Bar-Shavit R, Fuks Z. (1990) Cancer Metastasis Rev. 9: 203-226.

16. Leibovich SJ, Polverini PJ, Shepard HM, Wiseman D, Shively V, Nuseir N. (1987) $\mathrm{Na}$ ture 329: 630-632.

17. Gittes G. (1987) The neovascularization of metastases. Honors Thesis. Harvard Medical School.

18. Rastinejad F, Polverini PJ, Bouck NP. (1989) Cell 56: 345-355.

19. Good DJ, Polverini PJ, Radtinejad F, Le Beau MM, Lemons RS, Frazier WA, Bouck NP. (1990) Proc. Natl. Acad. Sci. U.S.A. 87: 66246628.

20. Dameron KM, Volpert OV, Tainsky MA, Bouck NP. (1994) Science 265: 1582-1584.

21. O'Reilly MS, Holmgren L, Shing Y, Chen C, Rosenthal RA, Moses M, Lane WS, Cao Y, Sage EH, Folkman J. (1994) Cell 79: 1-20.

22. Prehn RT. (1991) Cancer Res. 51: 2-4.

23. Van Meir EG, Polverini PJ, Chazin VR, Huang H-JS, de Tribolet N, Cavenee WK. (1994) Nature Gen. 8: 171-176. 